\title{
A comparison of the exhaust emission from city buses fuelled with diesel oil and CNG
}

\author{
J. Merkisz ${ }^{1}$, M. Bajerlein ${ }^{1}$, M. Dobrzynski ${ }^{1}$ \& D. Michalak ${ }^{2}$ \\ ${ }^{1}$ Institute of Combustion Engines and Transport, \\ Poznan University of Technology, Poland \\ ${ }^{2}$ Solaris Bus \& Coach, Poland
}

\begin{abstract}
Due to a growing demand for fossil fuels such as crude oil or natural gas it became necessary to seek new alternative energy sources. A variety of scientific and research work has been targeted at finding and the exploitation of sources of shale gas. According to the estimates, only in Poland there can be as much as 5.3 trillion cubic meters of natural gas trapped in unconventional sources. Such a potential can be utilized by many branches of economy including transport. It has become reasonable to use natural gas as an alternative fuel for utility vehicles. This paper presents the results of exhaust emission tests conducted on city buses fueled with diesel oil and CNG. The tests were conducted under actual traffic conditions on a regular bus route in Poznań. For the measurement of the exhaust emissions a portable exhaust emission analyzer Semtech DS was used. The obtained data were used for the determination of the average values of the emission of individual exhaust components. These values have shown that using different types of fuel in public transportation leads to a reduction of air pollution, and thus a better quality of life in the city.

Keywords: alternative energy sources, utility vehicles, exhaust emissions.
\end{abstract}

\section{Introduction}

According to research conducted by IEA (International Energy Agency) the world demand for fundamental energy carriers in 2008 was $5.12 \cdot 10^{11}$ GJ. As compared to 1973 this demand grew by approximately 50\% [1]. The main energy carriers exploited today by man are: crude oil, coal and natural gas. In the OECD group (Organization for Economic Co-operation and Development) 
crude oil had the greatest share in the energy demand in 2011 and this share amounted to $37.2 \%$. Natural gas held the second position with a share of 24.2\% [1]. The world production of natural gas, starting from 1971 until 2011, increased almost three times and today it amounts to approximately $3500 \mathrm{Tm}^{3}$ (Fig. 1).

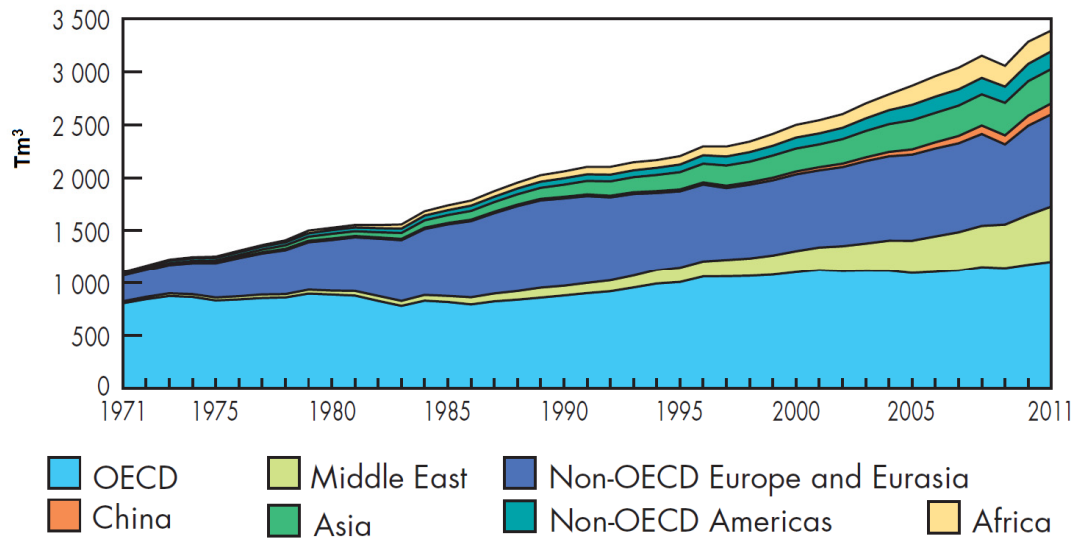

Figure 1: $\quad$ World production of natural gas in the years 1971-2011 [1].

A growing demand and a shortage of production of NG (natural gas) in the United States have caused a search for new sources of this fuel. The effect of intense research works continuing for over 20 years is the discovery and exploitation of natural gas from unconventional sources. This term in general refers to new types of gas sources that, due to specific excavation technology, are not exploited by the crude oil industry. Today, thanks to the increased profitability and improvement of excavation technologies, it is possible to exploit shale gas or tight gas (gas trapped in deep parts of the sedimentary basins) [2].

\section{Possibilities of application of natural gas as a vehicle fuel}

Due to the worldwide policy of sustainable use of conventional energy sources a variety of works have been carried out related to the search for alternative energy sources that could be used to fuel vehicles. For the utility vehicle group (trucks and buses) the use of natural gas as a fuel has become the most advantageous option. These vehicles can be fueled with two types of natural gas: CNG (Compressed Natural Gas) and LNG (Liquefied Natural Gas). Most often vehicle manufacturers use the compressed form of natural gas due to its better properties in operation as compared to the liquefied form. CNG is compressed to the pressure of 20-25 MPa and during the whole compression process it remains in the gaseous state. Its calorific value is the highest of all engine fuels and amounts to $55.5 \mathrm{MJ} / \mathrm{kg}$. In the vehicles CNG is stored in special composite tanks according to the ECE R110 standard. LNG due to its low temperature of $-162^{\circ} \mathrm{C}$ 
must be stored in special cryogenic tanks, which significantly obstructs its operation [3-4].

Thanks to a high resistance of natural gas to knock combustion and its ease mixing with air (a faster obtainment of a homogenous mixture) CNG engines can operate in the Otto cycle similarly to gasoline-fueled engines. Due to a high value of the ignition activation energy, ignition systems of higher spark plug electrical discharge must be applied (min. $30 \mathrm{kV}$ ). CNG engines can be divided into two groups in terms of mixture formation: direct natural gas injection engines and engines forming the mixture of natural gas and air outside of the combustion chamber. Today, the most popular engines are those fitted with multipoint fuel injection systems. These engines can operate on both stoichiomteric and lean mixtures. High admissible limits of exhaust gases have led to a situation that CNG engines now operate on stoichiometric mixtures owing to the three-way catalyst fitted in the exhaust systems [4-5].

\section{Research methodology}

The aim of the conducted research was the comparison of the exhaust emissions from city buses fueled with diesel oil and compressed natural gas under actual traffic conditions. In order to most accurately reflect the operating conditions the authors decided to carry out the tests on an actual bus route in Poznań (operated by MPK Poznań - local bus operator). Bus line 76, as the most heavily loaded one in Poznań was selected for the tests (Fig. 2). Its length amounts to approximately $16 \mathrm{~km}$ and it has 43 bus stops. It starts in the northern part of the city, goes through the downtown area and ends in the southern part of the city near the A2 expressway. A large number of bus stops and the trajectory of the route are responsible for the high oscillation of the accelerations, which significantly influences the exhaust emissions and fuel consumption.

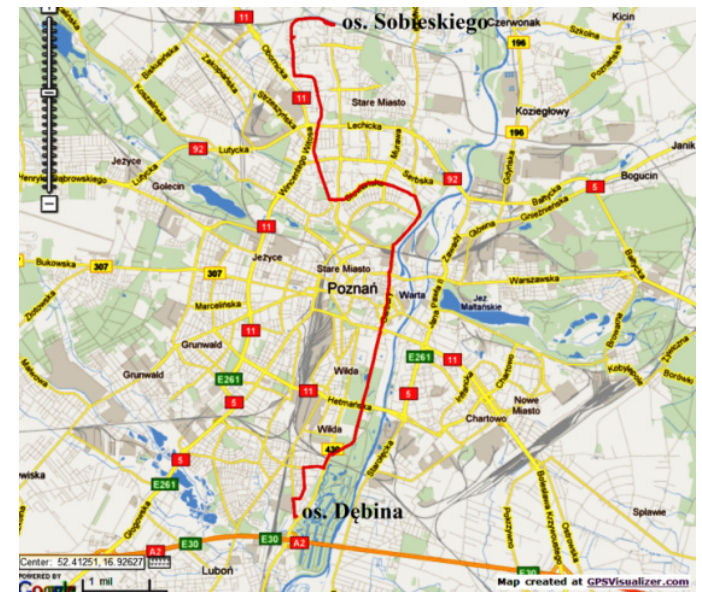

Figure 2: The route used for the vehicle emissions test (created at GPSVisualizer.com). 
For the tests two Urbino 18 buses by Solaris were used. They were fueled with diesel oil and compressed natural gas (tab. 1). The bus fueled with CNG was fitted with an engine of the displacement of $8.9 \mathrm{dm}^{3}$ and the power output of $238 \mathrm{~kW}$ operating in the Otto cycle. The vehicle was fitted with a three-way catalyst and an oxygen sensor operating in a closed loop. On the roof of the vehicle 8 composite tanks were fitted of the capacity of $214 \mathrm{dm}^{3}$ each. The tanks fitted on the roof increased the vehicle height to $3,400 \mathrm{~mm}$, which in many cases may pose a serious problem due to the city's specific infrastructure (underpass clearance, low overhead lines, etc.). The vehicle fueled with diesel oil had an engine of the displacement of $9.2 \mathrm{dm}^{3}$ and the power output of $231 \mathrm{~kW}$ (Fig. 3). The vehicle was fitted with a selective catalytic reduction system and diesel particulate filter. Both vehicles were the EEV standard compliant.

Table 1: $\quad$ Characteristics of the tested buses [6].

\begin{tabular}{|c|c|c|}
\hline \multirow{2}{*}{ Parameter } & Vehicle A & Vehicle B \\
\cline { 2 - 3 } & Solaris Urbino 18 CNG & Solaris Urbino 18 \\
\hline Ignition & Spark ignition & Compression ignition \\
\hline Displacement & $8.9 \mathrm{dm}^{3}$ & $9.2 \mathrm{dm}^{3}$ \\
\hline Number of cylinders & 6 & 6 \\
\hline $\begin{array}{c}\text { Maximum power } \\
\text { output }\end{array}$ & $235 \mathrm{~kW} @ 2000 \mathrm{rpm}$ & $231 \mathrm{~kW} @ 1900 \mathrm{rpm}$ \\
\hline Maximum torque & $1356 \mathrm{Nm}$ at & $1275 \mathrm{Nm}$ at \\
$1300 \mathrm{rpm}$ & $\mathrm{EEV}$ \\
\hline Emission standard & $\mathrm{EEV}$ & SCR/DPF \\
\hline After treatment & $\mathrm{TWC}$ & $18000 \mathrm{~mm}$ \\
\hline Length & $18000 \mathrm{~mm}$ & $3050 \mathrm{~mm}$ \\
\hline Height & $3400 \mathrm{~mm}$ & $24000 \mathrm{~kg}$ \\
\hline Weight & $24000 \mathrm{~kg}$ & $\mathrm{rpm}$ \\
\hline
\end{tabular}

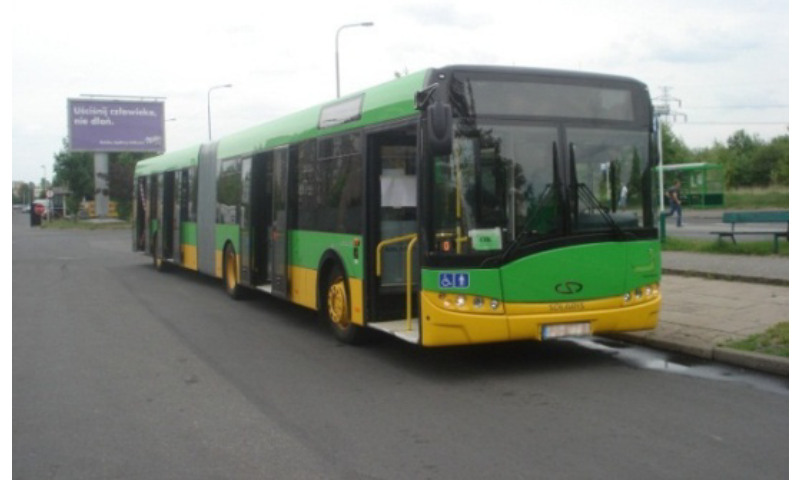

Figure 3: $\quad$ Vehicle B during the on-road emission tests. 
In order to measure the concentrations of the exhaust emission components a portable exhaust emissions analyzer SEMTECH DS by SENSORS was used (Fig. 4). The analyzer measures the concentration of the exhaust components and simultaneously measures the flow rate of the exhaust gases. The exhaust gases are introduced into the analyzer through a probe maintaining the temperature of $191^{\circ} \mathrm{C}$. Then, the particulate matter is filtered out (diesel engines) and the exhaust is directed to the flame-ionizing detector (FID) where HC (Hydrocarbons) concentration is measured. The exhaust gases are then cooled down to the temperature of $4^{\circ} \mathrm{C}$ and the measurement of the concentration of $\mathrm{NO}_{\mathrm{x}}$ (Nitric Oxides, NDUV analyzer), $\mathrm{CO}, \mathrm{CO}_{2}$ (Carbon Monoxide, Carbon Dioxide, NDIR analyzer) and $\mathrm{O}_{2}$ follows in the listed order. It is possible to add data sent directly from the vehicle diagnostic system to the central unit of the analyzer and use the GPS signal (Global Positioning System). The GPS signal is mainly used in the tests of on-road vehicles. In investigations similar to the ones presented here when the vehicle operates in a limited area, on-road emissions are not measured and GPS is of secondary importance. The test did not only comprise the measurements of the emissions but also, for the purpose of comparison, signals from the on-board diagnostic system (engine speed, load, vehicle speed, temperature of intake air). Some of these signals served to specify time density maps presenting the share of the operating time of the vehicles in the actual operation conditions [7-9].

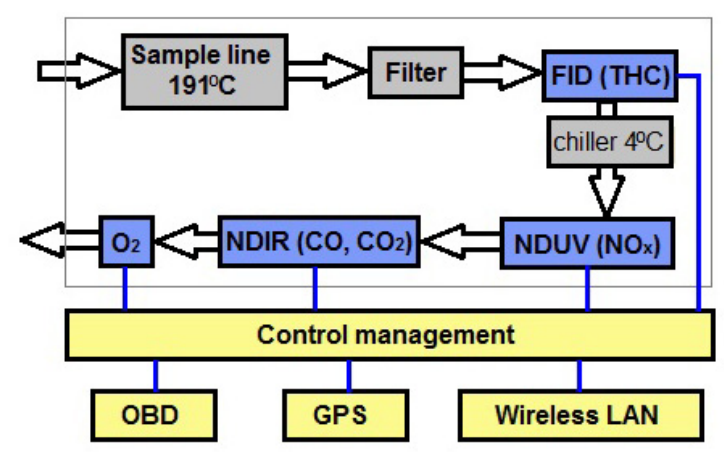

Figure 4: A diagram of a portable analyzer SEMTECH DS; exhaust gas flow channels (arrow) and electrical connections circled (blue line).

\section{Exhaust emission measurement results}

Based on the obtained values of the second-by-second emission of $\mathrm{CO}, \mathrm{NO}_{\mathrm{x}}, \mathrm{THC},\left(\mathrm{CH}_{4},+\mathrm{NMHC}\right), \mathrm{CO}_{2} \mathrm{f}$ and the speeds of the vehicles measured by the GPS systems during the tests, the operating time shares were determined in the intervals of speed and acceleration of the vehicles. Additionally, based on the data pulled from the on-board diagnostics of the vehicle engines, the operating time shares were determined in the intervals of the engine speed and 
engine load as well as the matrices of individual exhaust components in these same intervals.

For the CNG fueled vehicle two areas were distinguished of a significant operating time share (Fig. 5(a)). The first one was for the idling speed and amounted to $25 \%$, and the second was in the speed range of $8-14 \mathrm{~m} / \mathrm{s}$ (30$50 \mathrm{~km} / \mathrm{h}$ ) in the range of acceleration of $0-1.2 \mathrm{~m} / \mathrm{s}^{2}$ and constituted $44 \%$ of the total operating time of the vehicle. For the conventional diesel vehicle the main operating range was for the speeds of $0-18 \mathrm{~m} / \mathrm{s}(0-65 \mathrm{~km} / \mathrm{h})$ in the range of acceleration of $-0.6-1.2 \mathrm{~m} / \mathrm{s}^{2}$, which was similar to the CNG fueled vehicle (Fig. 5(b)). The greatest operating time share for the conventional diesel vehicle was for the idling speed and amounted to approximately 25\%. A similar distribution of the operating time in the intervals of speed and acceleration and the relative difference of the average speeds of the tested vehicles (4\%) confirm the reproducibility of the performed measurements. The above criteria allowed a comparison of the exhaust emissions of the tested vehicles under actual operation.

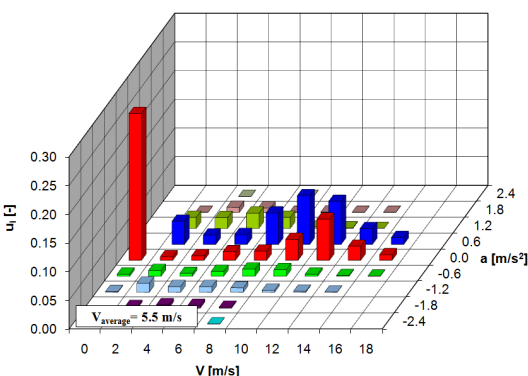

(a)

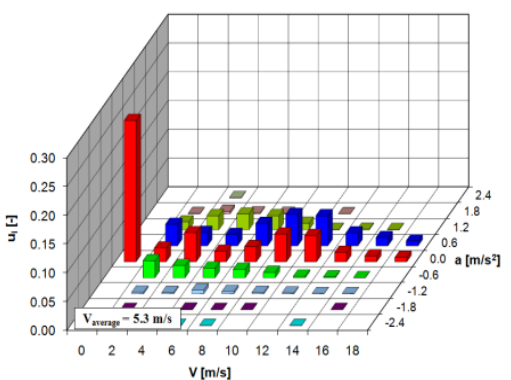

(b)

Figure 5: Characteristics of the operating time share in the intervals of vehicle speed and acceleration: (a) CNG fueled vehicle, (b) conventional diesel vehicle.

The main field of work of the CNG fueled vehicle can be divided into two characteristic ranges (Fig. 6(a)). The first, having the greatest operating time share, was for the idling speed (800 rpm at $400 \mathrm{Nm}$ ) and amounted to approximately $30 \%$. The other was in the range of $1000-1400 \mathrm{rpm}$ in the whole range of loads. It has also been observed that in the speed range 1000-1200 rpm the engine load grew gradually until reaching the maximum value of $1200 \mathrm{Nm}$. This confirms the operation of the engine under load characteristics described by the lowest specific fuel consumption. The conventional diesel vehicle was characterized by a greater operating area than the area of the CNG fueled engine and was in the range of 600-2200 rpm at 0-1400 Nm (Fig. 6(b)). The greatest operating time share was for the idling speed (600 rpm at $400 \mathrm{Nm}$ ) and amounted to $24 \%$. Another area of increased operating time share was high idle (800-1600 rpm) that constituted $18 \%$ of the total operating time. The authors also distinguished a $20 \%$ engine operating area that occurred for the highest 


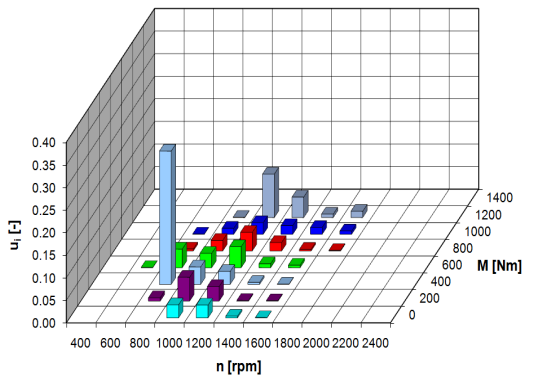

(a)

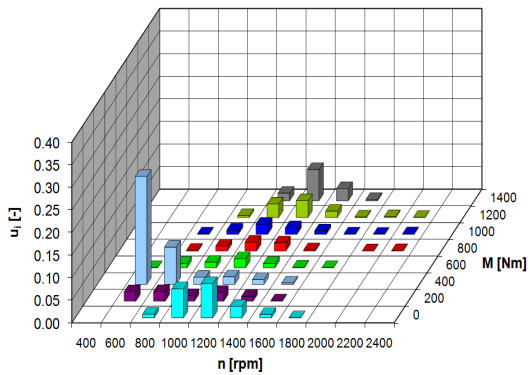

(b)

Figure 6: Characteristics of the operating time share in the intervals of engine speed and load: (a) CNG fueled vehicle, (b) conventional diesel vehicle.

engine loads. The only common feature of the engines of the tested vehicles was the greatest operating time share of the idling speed. The drives differed from one another.

The second-by-second emission of carbon monoxide of the CNG fueled vehicle had a characteristic course and its highest level occurred for the engine speed of $1600 \mathrm{rpm}$ and for the loads in the range of 1000-1200 Nm (Fig. 7(a)). Such a course was a result of the operating characteristics of the engine (the engine operated in the Otto cycle). In such a cycle at maximum loads the mixture is enriched, the effect of which is oxygen deficiency translating into an elevated emission of carbon monoxide. The average value of the second-by-second emission of CO for the CNG fueled vehicle was greater by $20 \%$ as compared to that of the conventional diesel vehicle. The conventional diesel vehicle had the highest second-by-second emission at the highest load, which resulted mainly from the increased fuel dose when driving off (Fig. 7(b)). This automatically translated into a reduction in the conversion rate of the oxidation catalyst fitted in the vehicle.

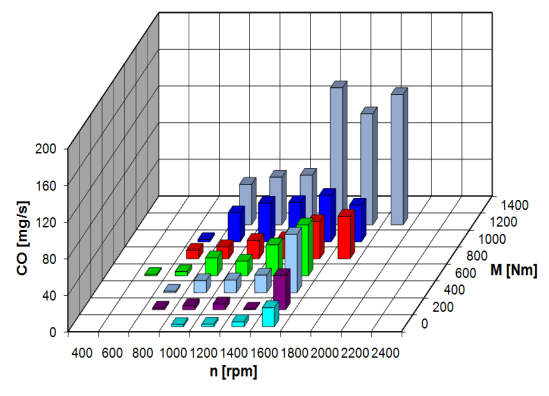

(a)

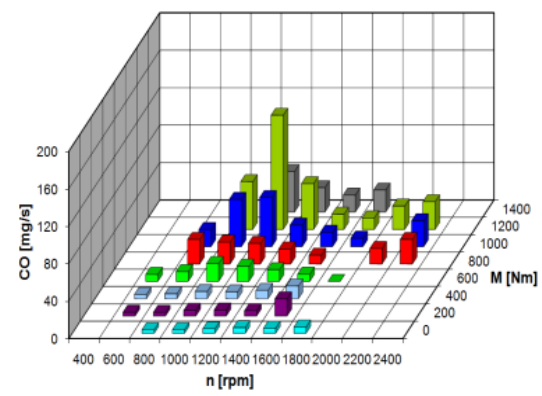

(b)

Figure 7: Characteristics of the share of the second-by-second emission of carbon monoxide in the intervals of engine speed and load: (a) CNG fueled vehicle, (b) conventional diesel vehicle. 
The course of the second-by-second emission of total hydrocarbons was similar (Fig. 7). The CNG fueled vehicle had a high level of the second-bysecond emission of THC that oscillated around $5-15 \mathrm{mg} / \mathrm{s}$ due to the course of the natural gas combustion whose products were also $\mathrm{CH}_{4}$ and $\mathrm{NMHC}$. The high accumulative value of the emission of total hydrocarbons mainly resulted from the content of methane in the exhaust gases caused by a lower conversion rate of the TWC for this compound.

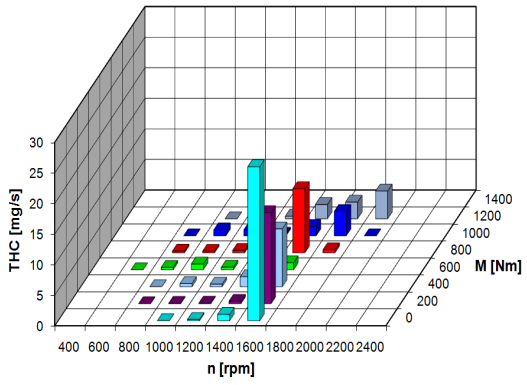

(a)

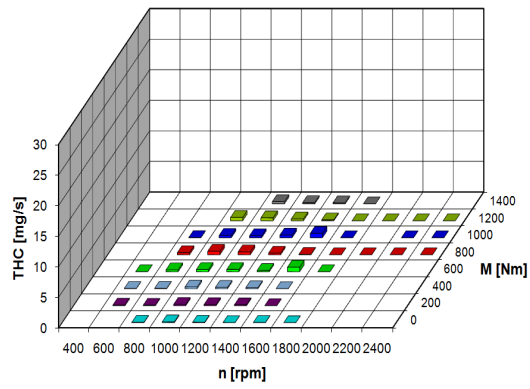

(b)

Figure 7: Characteristics of the share of the second-by-second emission of total hydrocarbons in the intervals of engine speed and load: (a) CNG fueled vehicle, (b) conventional diesel vehicle.

The second-by-second emission of nitric oxides was different. For the CNG fueled vehicle the highest emission of $\mathrm{NO}_{\mathrm{x}}$ occurred for medium and high loads (800-1200 Nm) and amounted to approximately $40 \mathrm{mg} / \mathrm{s}$ (Fig. 8(a)). The conventional diesel vehicle had a characteristic course of the second-by-second emission of $\mathrm{NO}_{\mathrm{x}}$ that grew as the engine speed and load increased (Fig. 8b). The authors also observed that its average value was 6 times higher than the average value of the second-by-second emission of $\mathrm{NO}_{\mathrm{x}}$ from the $\mathrm{CNG}$ fueled vehicle. This was chiefly caused by the high conversion rate of the three way catalytic converter that is the highest for a stoichiometric air-fuel mixture (based on the data pulled from the vehicle on-board diagnostic system and the mass flow rate of the exhaust gas, the value of the excess air coefficient was determined that, during the tests oscillated around 1.02-1.10). The conventional diesel vehicle was fitted with a SCR system the conversion rate of which is influenced by a variety of factors such as the exhaust gas mass flow and temperature. During onroad tests there is a high oscillation of accelerations, which is related to significant changes in the exhaust gas flow and its temperature. This fact has a substantial impact on the reduction of the conversion rate of the SCR system hence the high differences in the second-by-second emission of nitric oxides between the conventional and the CNG fueled vehicles.

The second-by-second emission of carbon dioxide for both tested vehicles had a similar course (Fig. 9). The said emission of $\mathrm{CO}_{2}$ grew as the engine speed and load increased. Its highest level occurred for the medium and maximum load: CNG fueled vehicle 800-1200 Nm, conventional vehicle 800-1400 Nm. 
Such a course is caused by a high energy demand of the vehicle resulting from the specificity of the test route characterized by both high congestion and numerous bus stops. This results in a frequent vehicle drive off and stoppage, hence the high energy demand translating into higher fuel consumption and $\mathrm{CO}_{2}$ emission.

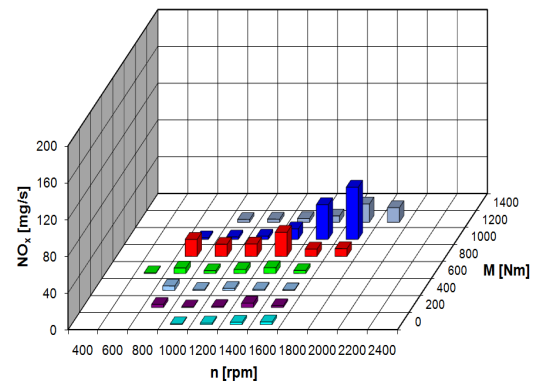

(a)

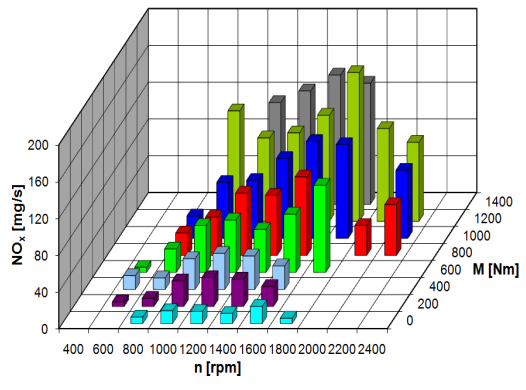

(b)

Figure 8: Characteristics of the share of the second-by-second emission of nitric oxides in the intervals of engine speed and load: a) CNG fueled vehicle, b) conventional diesel vehicle.

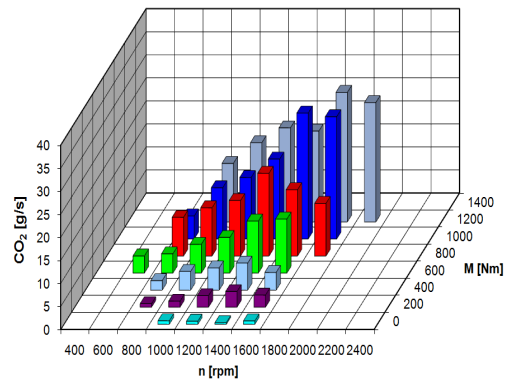

(a)

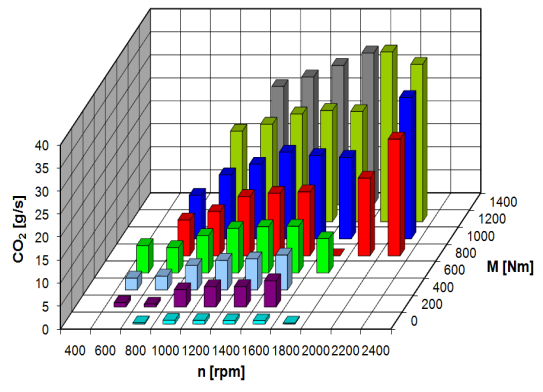

(b)

Figure 9: Characteristics of the share of the second-by-second emission of carbon dioxide in the intervals of engine speed and load: (a) CNG fueled vehicle, (b) conventional diesel vehicle.

\section{Conclusions}

From the data obtained during the exhaust emission tests of diesel and CNG fueled vehicles under actual conditions of operation on bus route number 76 in Poznań it results that the specific emission of the CNG fueled vehicle as compared to the emission of the conventional vehicle was as follows (Fig. 10):
a) the emission of $\mathrm{CO}_{2}$ was lower by $22 \%$,
b) the emission of $\mathrm{CO}$ was greater by $23 \%$,
c) the emission of $\mathrm{NO}_{\mathrm{x}}$ was lower by $72 \%$,
d) the emission of THC was greater by $127 \%$. 
Such a structure of the specific exhaust emissions resulted mainly from the properties of the applied fuels and the type of thermodynamic cycle in which the engines operated. Because of the said differences the tested vehicles were also fitted with different after treatment systems. The obtained results of the tests confirm the applicability of natural gas as an alternative fuel for utility vehicles. Additionally, to reduce the negative environmental impact and fuel consumption of these vehicles it is recommended to implement CNG fueled engines to hybrid power trains. To this end it is necessary to conduct exhaust emission tests under actual traffic conditions using PEMS. The tests will not only provide invaluable information on the exhaust emissions but will also serve the purpose of determination of the energy balance and driving cycles for individual agglomerations.

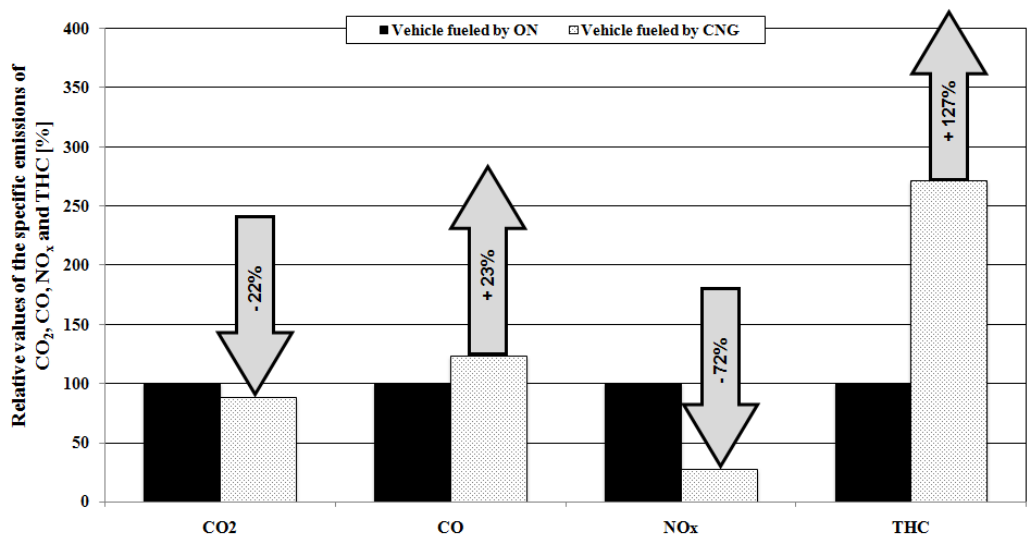

Figure 10: Relative values of the specific emissions obtained during the onroad tests.

\section{References}

[1] IEA Statistics: Key World Energy Statistics 2012; France, (2012).

[2] Walsh M.P.: Global trends in motor vehicle pollution control; a 2011 update. Part 1. Combustion Engines / Silniki Spalinowe nr 2/2011 (145), pp. 106-117, (2011).

[3] Ambrozik A.: Wybrane zagadnienia procesów cieplnych w tłokowych silnikach spalinowych; Wyd. Politechnika Świętokrzyska, Poland, (2003).

[4] Romaniszyn K. M.: Alternatywne zasilanie samochodów benzyną oraz gazami LPG i CNG. Badania porównawcze dynamiki rozpędzania i emisji spalin, WNT, Warszawa, Poland, (2007).

[5] Kruczynski S., Wołoszyn R., Stępniewski M.: Spalanie mieszanki gazu ziemnego z powietrzem w silniku o zapłonie iskrowym; CombustionEngines /Silniki Spalinowe nr 3/2011 (146), (2011).

[6] Information from vehicle producer. 
[7] Merkisz J., Fuc P.: The Exhaust Emission from Light Duty Vehicles in Road Test in Urban Traffic. SAE Technical Paper Series 2010-01-1558, (2010).

[8] Merkisz J., Pielecha J., Fuc P., Lijewski P., The analysis of the PEMS measurements of the exhaust emissions from city buses using different research procedures. The 8th IEEE Vehicle Power and Propulsion Conference VPPC 2012, Org. KIEE, Paper No. F20120618-0339 Seul 9-12.10.2012, pp. 903-907.

[9] Merkisz J., Idzior M., Pielecha J., Gis. W., Emission tests in city buses under real road conditions. Book "Urban Transport XVI - Urban Transport and the Environment in the 21st Century”, Edited by A. Pratelli and C.A. Brebbia. WIT Transactions. WIT Press 2010, Wessex, UK, pp. 181-189. 